\title{
Pengaruh Beban Kerja Terhadap Produktivitas Kerja Karyawan Pada PT. Bank Syariah Mandiri Cabang Harapan Raya Pekanbaru
}

\author{
Mhd. Suleman Hsb ${ }^{1}$ \& Fitriyanti ${ }^{2 *}$ \\ *Sekolah Tinggi Ilmu Ekonomi Prakarty Mulya \\ Jl. Arifin Ahmad No.58 Pekanbaru \\ e-mail : hsb.suleman@gmail.com
}

\begin{abstract}
Abstrak: Tujuan penelitian ini adalah untuk mengetahui pengaruh beban kerja terhadap produktivitas kerja karyawan pada PT. Bank Syariah Mandiri Cabang Harapan Raya Pekanbaru. Sampel dalam penelitian ini adalah seluruh karyawan pada PT. Bank Syariah Mandiri Cabang Harapan Raya Pekanbaru yang berjumlah 42 orang. Pengambilan sampel dilakukan dengan menggunakan sampel jenuh. Sedangkan variabel yang diteliti dalam penelitian ini adalah beban kerja dan produktivitas karyawan. Analisis data menggunakan metode regresi linear sederhana dengan menggunakan uji validitas, reliabilitas, R2 dan uji t. Pengujian tersebut dilakukan guna mengetahui hubungan antara variabel bebas (independen variable) dengan variabel terikat (dependent variable). Berdasarkan hasil penelitian bahwa beban kerja secara serentak berpengaruh terhadap produktivitas kerja karyawan dengan nilai korelasi $\mathrm{R}=0,669$ yang menunjukkan adanya hubungan yang erat antara beban kerja dengan produktivitas kerja karyawan pada PT. Bank Syariah Mandiri Cabang Harapan Raya Pekanbaru. Sedangkan R square di dapat 0,448 yang berarti beban kerja memiliki kontribusi sumbangan sebesar 44,8\% terhadap produktivitas karyawan pada PT. Bank Syariah Mandiri Cabang Harapan Raya Pekanbaru. Secara parsial diperoleh variable beban kerja berpengaruh positif dan signifikan terhadap produktivitas kerja karyawan pada PT. Bank Syariah Mandiri Cabang Harapan Raya Pekanbaru dengan persamaan regresi linear sederhana sebagai berikut : $Y=20,214+0,789 X$ dengan signifikan 0,000 lebih kecil dari alpha 0,05. Kesimpulan dari penelitian bahwa hipotesis secara parsial antara variable beban kerja terhadap produktivitas kerja karyawan terbukti dan dapat diterima kebenarannya.
\end{abstract}

Kata Kunci: Beban Kerja, Produktivitas Kerja Karyawan. 


\section{PENDAHULUAN}

Peran manusia dalam perusahaan sebagai karyawan, memegang peranan yang menentukan hidup matinya sebuah perusahaan tergantung dari kinerja para karyawannya. Kinerja karyawan dapat berfungsi dengan baik apabila karyawan dapat bekerja dengan maksimal. Karyawan merupakan faktor penting dalam setiap perusahaan karena para karyawan merupakan faktor penentu dalam pencapaian tujuan perusahaan secara efektif dan efisien. Karyawan merupakan penggerak dan penentu jalannya sebuah perusahaan, sehingga kemajuan sebuah perusahaan tergantung dari sistem kerja para karyawannya.

Karyawan merupakan elemen yang harus diperhatikan oleh perusahaan terutama karena dunia perbankan merupakan perusahaan yang bergerak dibidang jasa keuangan, sehingga para karyawan dituntut untuk dapat bekerja

Tabel 1.

Beban Kerja Karyawan

PT. Bank Syariah Mandiri Cabang Harapan Raya Pekanbaru Tahun 2017 sebaik mungkin serta dengan usaha yang maksimal. Hal ini memaksa karyawan harus dapat bekerja secara efektif dan efisien serta produktif untuk mencapai tujuan yang diinginkan oleh perusahaan. Karyawan merupakan penggerak kegiatan dalam suatu perusahaan. Dalam melakukan kegiatan, karyawan memerlukan petunjuk kerja dari perusahaan agar pelaksanaan kerja sesuai dengan peraturan kerja perusahaan. Pelaksanaan sistem kerja harus dilakukan dengan baik oleh para karyawannya karena akan menyebabkan menurunnya produktivitas kerja yang akan dihasilkan oleh para karyawan. Produktivitas kerja karyawan harus sangat diperhatikan karena merupakan salah satu kunci keberhasilan perusahaan. Berikut ini adalah data beban kerja yang dilakukan karyawan pada PT. Bank Syariah Mandiri Cabang Harapan Raya Pekanbaru pada tahun 2017 :

\begin{tabular}{|c|c|c|}
\hline No & Bagian Tugas & Beban Kerja Karyawan (Hari/Bulan) \\
\hline 1. & Kepala Cabang & $\begin{array}{l}\text { a. Dapat mengontrol semua pekerjaan yang dilakukan oleh } \\
\text { karyawan di seluruh devisi } \\
\text { b. Dapat melakukan pencairan di seluruh devisi minimal } \\
10 \text { NOA perhari }\end{array}$ \\
\hline 2. & Marketing Manager & $\begin{array}{l}\text { a. Dapat melakukan survey lapangan minimal } 5 \text { NOA } \\
\text { perhari } \\
\text { b. Dapat mencairkan nasabah minimal } 2 \text { NOA perhari. } \\
\text { c. Dapat mencapai taget perbulannya }>1 \text { milyar. }\end{array}$ \\
\hline 3. & Service Manager & $\begin{array}{l}\text { Dapat mengontrol transaksi yang dilakukan oleh CS dan } \\
\text { teller. }\end{array}$ \\
\hline 4. & $\begin{array}{l}\text { Priority } \\
\text { Officer }\end{array}$ & Dapat memasukan dana nasabah perhari minimal 5 NOA. \\
\hline 5. & Account Officer & Dapat \\
\hline 6. & Gadai Officer & Dapat mencari nasabah minimal 10 NOA per hari \\
\hline 7. & $\begin{array}{l}\text { General } \\
\text { Assistant }\end{array}$ & $\begin{array}{l}\text { Membantu semua marketing dalam menginput data BI } \\
\text { Checking ke Bank Indonesia }\end{array}$ \\
\hline 8. & $\begin{array}{l}\text { Domestic } \\
\text { Clearing }\end{array}$ & $\begin{array}{l}\text { a.Mengontrol driver dan office boy dalam melakukan } \\
\text { pekerjaan. } \\
\text { b. Mengecek persediaan peralatan kantor yang dibutuhkan }\end{array}$ \\
\hline
\end{tabular}


oleh karyawan.

9. Teller

10. Customer Service

11. RPFO Pembiayaan)

12. Assisten Analisis Mikro

13. Sales Assistant

14. Pelaksana Penaksir Gadai

15. Pelaksana Marketing Mikro

16. Office Boy

17. Driver

18. Security
Dapat bertransaksi dengan nasabah minimal 10 menit perorangnya.

a.Dapat membuka buku rekening minimal 5 menit perorang

b. Dapat membantu dalam meningkatkan dana funding minimal 10 juta perhari

Dapat membantu pencairan nasabah dan membuat akad minimal 5 noa perhari

a. Dapat melakukan survey lapangan minimal 5 noa perhari

b. Dapat membuat NAP minimal 3 noa perhari

Dapat mencari nasabah funding minimal 3 noa perhari

Dapat mencari nasabah minimal 10 noa perhari

Dapat memberikan pembiayaan Rp.350.000.000/bulan

Membersihkan seluruh ruangan yang ada di perusahaan Mengantarkan karyawan dalam melakukan pekerjaan Menjaga dan membuka pintu bagi nasabah yang datang berkunjung ke bank

Sumber : PT. Bank Syariah Mandiri Cabang Harapan Raya Pekanbaru, 2018.

Dari tabel 1 dapat dilihat beban kerja karyawan PT. Bank Syariah Mandiri Cabang Harapan Raya Pekanbaru setiap harinya berbeda sesuai dengan jabatan yang diemban masing-masing karyawan. Semakin baik karyawan melakukan pekerjaannya maka kinerja yang dihasilkannya juga akan mengalami peningkatan. Berikut ini adalah jumlah karyawan yang bekerja pada PT. Bank Syariah Mandiri Cabang Harapan Raya Pekanbaru dari tahun 2013-2017 :

Tabel 2.

Jumlah Karyawan PT. Bank Syariah Mandiri Cabang Harapan Raya Pekanbaru Tahun 2013-2017

\begin{tabular}{lll}
\hline Tahun & Jumlah Karyawan & Perkembangan (\%) \\
\hline 2013 & 35 & $40 \%$ \\
2014 & 38 & $8,57 \%$ \\
2015 & 40 & $5,26 \%$ \\
2016 & 42 & $5 \%$ \\
2017 & 42 & - \\
\hline
\end{tabular}

Sumber : PT. Bank Syariah Mandiri Cabang Harapan Raya Pekanbaru, 2018.

Dari tabel 2 dapat dilihat data target Syariah Mandiri Cabang Harapan Raya dan realisasi kerja karyawan PT. Bank Pekanbaru setiap tahunnya mengalami 
fluktuasi. Hal ini dikarenakan oleh beberapa faktor yang salah satunya karena menurunnya produktivitas kerja karyawan. Produktivitas kerja karyawan dapat menurun akibatnya besarnya beban kerja yang diberikan oleh perusahaan serta pangsa pasar yang dikerjakan oleh karyawan semakin sepi sehingga kinerja yang dihasilkan oleh karyawan mengalami penurunan. Dari tabel dibawah ini, dapat dilihat bagaimana gambaran tentang produktivitas kerja karyawan pada PT. Bank Syariah Mandiri Cabang Harapan Raya Pekanbaru yang dapat dilihat dari target marketing funding dari tahun 20132017

Tabel 3.

Data Target Dan Realisasi Lending PT. Bank Syariah Mandiri Cabang Harapan Raya Pekanbaru Tahun 2013-2017

\begin{tabular}{|c|c|c|c|}
\hline Tahun & $\begin{array}{l}\text { Target } \\
\text { (Rupiah) }\end{array}$ & Realisasi (Rupiah) & $\begin{array}{l}\text { Pencapaian( } \\
\text { \%) }\end{array}$ \\
\hline 2013 & 20.955 .876 .378 .35 & 17.957 .375 .236 .49 & $85,69 \%$ \\
\hline 2014 & 23.679 .559 .239 .47 & 22.968 .752 .649 .52 & $96,99 \%$ \\
\hline 2015 & 25.976 .890 .234 .54 & 24.754 .900 .543 .23 & $95,30 \%$ \\
\hline 2016 & 27.798.457.655.99 & 25.268 .544 .551 .23 & $90,90 \%$ \\
\hline 2017 & 30.687 .950 .432 .76 & 26.765 .890 .950 .27 & $87,22 \%$ \\
\hline
\end{tabular}

Sumber : PT. Bank Syariah Mandiri Cabang Harapan Raya Pekanbaru, 2018.

Dari tabel 3 dapat dilihat bahwa pencapaian target marketing funding pada PT. Bank Syariah Mandiri Cabang Harapan Raya Pekanbaru, dalam beberapa tahun mengalami penurunan tetapi pada tahun berikutnya mengalami peningkatan. Dari tabel di bawah ini juga dapat dilihat

produktivitas kerja karyawan bagian operasional dari jumlah pembukaan rekening nasabah, dimana dapat diartikan bahwa PT. Bank Syariah Mandiri Cabang Harapan Raya Pekanbaru diminati oleh masyarakat kota Pekanbaru dari tahun 2013-2017:

Tabel 4.

Data Target Dan Realisasi Lending PT. Bank Syariah Mandiri Cabang Harapan Raya Pekanbaru Tahun 2013-2017

\begin{tabular}{lll}
\hline Tahun & Jumlah Account (NOA) & Perkembangan Nasabah (\%) \\
\hline 2013 & 15.978 & - \\
2014 & 20.345 & $27.3 \%$ \\
2015 & 24.501 & $20.4 \%$ \\
2016 & 23.763 & $-3.0 \%$ \\
2017 & 24.237 & $1.9 \%$ \\
\hline
\end{tabular}

Sumber : PT. Bank Syariah Mandiri Cabang Harapan Raya Pekanbaru, 2018.

Dari tabel 4 dapat dilihat data laporan pembukaan rekening diatas, dapat dilihat pada tahun 2013 jumlah account terus bertambah dan hanya pada tahun 2016 yang mengalami sedikit penurunan account. Hal ini disebabkan karena menurunnya produktivitas kerja yang dilakukan oleh karyawan sehingga beban kerja yang telah ditetapkan oleh perusahaan tidak dapat tercapai dengan maksimal.

\section{TINJAUAN PUSTAKA Pengertian Bank}

Secara sederhana bank diartikan sebagai lembaga keuangan yang kegiatan usahanya adalah menghimpun dana dari masyarakat serta memberikan jasa-jasa 
bank lainnya. Bank syariah adalah bank yang beroperasi dengan tidak mengandalkan pada bunga, dan juga disebut dengan lembaga keuangan/perbankan yang operasional dan produknya dikembangkan berlandaskan pada Alquran dan hadist Nabi Muhammad SAW (Zulkifli dkk, 2020). Lembaga keuangan adalah setiap perusahaan yang bergerak dibidang keuangan dimana kegiatannya apakah hanya menghimpun dana atau hanya menjalankan dana dan atau kedua-duanya. (Kasmir, 2012:20-21). Sesuai dengan Undang-Undang Perbankan No 7 Tahun 1992 dan ditegaskan lagi dengan keluarnya Undang-Undang RI Nomor 10 Tahun 1998, maka jenis perbankan berdasarkan fungsinya terdiri dari Bank Umum dan Bank Prekkreditan Rakyat (BPR).

\section{Pengertian Manajemen Sumber Daya Manusia}

Manajemen Sumber Daya Manusia dapat didefiniskan sebagai suatu proses perencanaan, pengorganisasian, penyusunan staf, penggerakan, dan pengawasan, terhadap pengadaan, pengembangan, pemberian kompensasi, pengintegrasian, pemeliharaan dan pemisahaan tenaga kerja untuk mencapai tujuan organisasi (Bangun, 2012:6). Manajemen sumber daya manusia (MSDM) merupakan bidang strategis dari organisasi. Manajemen sumber daya manusia (MSDM) dapat diartikan sebagai kegiatan perencanaan, pengadaan, pengembangan, pemeliharaan serta penggunaan SDM untuk mencapai tujuan yang baik secara individu maupun organisasi (Sutrisno, 2015:6). Fungsi -Fungsi Manajemen Sumber Daya Manusia menurut Wilson Bangun (2012:713) dapat dijabarkan dalam 5 fungsi yaitu : Pengadaan Sumber Daya Manusia, Pengembangan Sumber Daya Manusia, Pemberian Kompensasi Pengintegrasian dan Pemeliharaan Sumber Daya Manusia.

\section{Produktivitas Kerja}

Produktivitas secara umum diartikan sebagai hubungan antara keluaran (barang atau jasa) dengan masukan (tenaga kerja, bahan, uang). Produktivitas adalah ukuran efisiensi produktif. Suatu perbandingan antara hasil keluaran dan masukan. Masukan sering dibatasai dengan tenaga kerja sedangkan keluaran diukur dalam kesatuan fisik, bentuk dan nilai. (Sutrisno, 2015:99)

Secara teknis produktivitas merupakan perbandingan antara hasil yang dicapai dan keseluruhan sumber daya yang dipergunakan, produktivitas tenaga kerja merupakan perbandingan antara hasil yang dicapai dengan pasar tenaga kerja per satuan waktu dan sebagai tolok ukur jika ekspansi dan aktifitas dari sikap sumber yang digunakan selama produktivitas berlangsung dengan membandingkan jumlah yang dihasilkan dengan setiap sumber yang digunakan.

Menurut Danang Sunyoto (2012:41) secara filosofi, produktivitas merupakan sikap mental yang selalu berusaha dan mempunyai pandangan bahwa suatu kehidupan hari ini lebih baik dari hari kemarin dan hari esok lebih baik dari hari ini. Produktivitas adalah sikap mental yang selalu berpandangan bahwa mutu kehidupan hari ini harus lebih baik dari hari kemarin dan hari esok lebih baik dari hari ini.

\section{Upaya Peningkatan Produktivitas}

Bahwa peningkatan produktivitas kerja dapat dilihat sebagai masalah keperilakuan, tetapi juga dapat mengandung aspek-aspek teknis. Untuk mengatasi hal itu perlu pemahaman yang tepat tentang faktor-faktor penentu keberhasilan meningkatkan produktivitas kerja. Adapun faktor-faktor tersebut menurut siagian dalam Sutrisno (2015:105) adalah Perbaikan terus menerus, Peningkatan Mutu Hasil 
Pekerjaan dan Pemberdayaan Sumber Daya Manusia.

\section{Indiktor Produktivitas Kerja}

Produktivitas merupakan hal yang sangat penting bagi para karyawan yang ada diperusahaan. Dengan adanya produktivitas kerja diharapkan pekerjaan akan terlaksana secara efisien dan efektif sehingga ini semua akhirnya sangat diperlukan dalam pencapaian.

Tujuan yang sudah ditetapkan. Untuk mengukur produktivitas kerja, diperlukan suatu indikator, yaitu sebagai berikut : (Sutrisno, 2015:104-105) Kemampuan, Meningkatkan hasil yang dicapai, Semangat kerja, Pengembangan diri, Efisiensi.

\section{Beban Kerja}

Setiap pekerjaan merupakan beban bagi yang bersangkutan, beban tersebut dapat berupa beban fisik maupun mental. (Tarwaka, 2004:95) Menurut Everly dan Girdano dalam Munandar (2001:45) beban kerja adalah keadaan dimana pekerja dihadapkan pada tugas yang harus diselesaikan pada waktu tertentu. Menurut Ali (2002:63) beban kerja adalah sesuatu yang terasa memberatkan yang sukar untuk dikerjakan sebagai tanggungan.

\section{METODE PENELITIAN}

Penelitian ini dilaksanakan pada PT. Bank Syariah Mandiri Cabang Harapan Raya, adapun lokasi penelitian yang dijadikan objek penelitian ini adalah PT. Bank Syariah Mandiri Cabang Harapan Raya yang beralamat di Jalan Imam Munandar Pekanbaru-Riau.

Adapun jenis data yang penulis kumpulkan adalah : Data Primer Data primer yaitu data yang langsung diperoleh dari objek penelitian. (Sugiyono, 2010:14) Melalui kuisioner dan wawancara langsung dengan pimpinan dan karyawan PT. Bank Syariah Mandiri Cabang Harapan Raya dan data sekunder berupa data yang sudah tersedia seperti data jumlah karyawan, struktur organisasi dan aktifitas perusahaan serta data lainnya yang mendukung analisa dalam penelitian ini.

Menurut Suharsimi Arikunto (2010:173) Populasi adalah keseluruhan subyek penelitian. Adapun yang menjadi populasi dalam penelitian ini adalah seluruh karyawan pada PT. Bank Syariah Mandiri Cabang Harapan Raya yang berjumlah 42 orang. Sampel yang diambil dalam penelitian ini adalah seluruh karyawan PT. Bank Syariah Mandiri Cabang Harapan Raya yang berjumlah 42 orang.

\section{PEMBAHASAN}

Analisis Tanggapan Responden Mengenai Beban Kerja Pada PT. Bank Syariah Mandiri Cabang Harapan Raya Pekanbaru

Berikut ini adalah hasil tanggapan responden mengenai indikator beban kerja pada PT. Bank Syariah Mandiri Cabang Harapan Raya Pekanbaru :

1. Tanggapan responden tentang target yang diberikan perusahaan sesuai dengan kemampuan yang dimiliki karyawan. Kategori sangat setuju ada sebanyak 9 orang $(21,43 \%)$, kategori setuju ada sebanyak 25 orang $(59,52 \%), 8$ orang $(19,05 \%)$ pada kategori cukup setuju sedangkan pada kategori tidak setuju dan sangat tidak setuju tidak ada jawaban responden. Adapun nilai rata-rata adalah 4,02. Hal ini menunjukkan bahwa target yang diberikan perusahaan sesuai dengan kemampuan yang dimiliki karyawan adalah setuju.

2. Tanggapan responden tentang karyawan dapat mencapai target kerja yang telah ditetapkan Kategori sangat setuju ada sebanyak 9 orang $(21,43 \%)$, kategori setuju ada sebanyak 25 orang $(59,52 \%), \quad 8$ orang $(19,05 \%)$ pada kategori cukup setuju sedangkan pada 
kategori tidak setuju dan sangat tidak setuju tidak ada jawaban responden. Adapun nilai rata-rata adalah 4,02. Hal ini menunjukkan bahwa target yang diberikan perusahaan sesuai dengan kemampuan yang dimiliki karyawan adalah setuju.

3. Tanggapan responden tentang karyawan dapat mencapai target kerja yang telah ditetapkan. Kategori sangat setuju ada sebanyak 7 orang $(16,67 \%)$, kategori setuju ada sebanyak 26 orang (61,90\%), kategori cukup setuju ada sebanyak 9 orang $(21,43 \%)$ sedangkan kategori tidak setuju dan sangat tidak setuju tidak ada jawaban responden. Adapun nilai rata-rata adalah 3,95. Hal ini menunjukkan bahwa karyawan dapat mencapai target kerja yang telah ditetapkan adalah setuju.

4. Tanggapan responden tentang karyawan dapat menyelesaikan target kerja sesuai dengan jangka waktu yang diberikan. Kategori sangat setuju ada sebanyak 7 orang $(16,67 \%)$, kategori setuju ada sebanyak 25 orang (59,52\%), kategori cukup setuju ada sebanyak 10 orang $(23,81 \%)$ sedangkan kategori tidak setuju dan sangat tidak setuju tidak ada jawaban responden. Adapun nilai rata-rata adalah 3,93. Hal ini menunjukkan bahwa karyawan dapat menyelesaikan target kerja sesuai dengan jangka waktu yang diberikan adalah setuju.

5. Tanggapan responden tentang karyawan dapat memahami pekerjaan yang diberikan kepada nya. Kategori sangat setuju ada sebanyak 9 orang $(21,43 \%)$, kategori setuju ada sebanyak 24 orang $(57,14 \%)$, kategori cukup setuju ada sebanyak 8 orang $(19,05 \%)$, kategori tidak setuju ada sebanyak 1 orang $(2,38 \%)$ sedangkan kategori sangat tidak setuju tidak ada jawaban responden. Adapun nilai rata-rata adalah 3,98. Hal ini menunjukkan bahwa karyawan dapat memahami pekerjaan yang diberikan kepadanya adalah setuju.

6. Tanggapan responden tentang karyawan memiliki inisiatif yang baik dalam melakukan pekerjaan dapat. Kategori sangat setuju ada sebanyak 7 orang $(16,67 \%)$, kategori setuju ada sebanyak 23 orang $(54,76 \%)$, kategori cukup setuju ada sebanyak 12 orang (28,57\%) sedangkan kategori tidak setuju dan sangat tidak setuju tidak ada jawaban responden. Adapun nilai ratarata adalah 3,88. Hal ini menunjukkan bahwa karyawan memiliki inisiatif yang baik dalam melakukan pekerjaan adalah setuju.

7. Tanggapan responden tentang karyawan dapat melakukan pekerjaan diluar pekerjaan yang telah ditentukan. Kategori sangat setuju ada sebanyak 13 orang (30,95\%), kategori setuju ada sebanyak 20 orang $(47,62 \%)$, kategori cukup setuju ada sebanyak 9 orang $(21,43 \%)$ sedangkan kategori tidak setuju dan sangat tidak setuju tidak ada jawaban responden. Adapun nilai ratarata adalah 4,10. Hal ini menunjukkan bahwa karyawan dapat melakukan pekerjaan diluar pekerjaan yang telah ditentukan adalah setuju.

8. Tanggapan responden tentang beban kerja yang diberikan perusahaan sesuai dengan standar kerja yang telah ditetapkan. Kategori sangat setuju ada sebanyak 11 orang $(26,19 \%)$, kategori setuju ada sebanyak 22 orang (52,38\%), kategori cukup setuju ada sebanyak 9 orang $(21,43 \%)$ sedangkan kategori tidak setuju dan sangat tidak setuju tidak ada jawaban responden. Adapun nilai rata-rata adalah 4,05. Hal ini menunjukkan bahwa beban kerja yang diberikan perusahaan sesuai 
dengan standar kerja yang telah ditetapkan adalah setuju.

9. Tanggapan responden tentang karyawan memiliki perasaan yang baik dalam memenuhi standar kerja yang ditetapkan dapat. Kategori sangat setuju ada sebanyak 13 orang $(30,95 \%)$, kategori setuju ada sebanyak 19 orang (45,24\%), kategori cukup setuju ada sebanyak 10 orang $(23,81 \%)$ sedangkan kategori tidak setuju dan sangat tidak setuju tidak ada jawaban responden. Adapun nilai rata-rata adalah 4,07. Hal ini menunjukkan bahwa karyawan memiliki perasaan yang baik dalam memenuhi standar kerja yang ditetapkan adalahsetuju.

10. Tanggapan responden tentang karyawan selalu mematuhi standar yang ditetapkan oleh perusahaan. Kategori sangat setuju ada sebanyak 12 orang $(28,57 \%)$, kategori setuju ada sebanyak 22 orang $(52,38 \%)$, kategori cukup setuju ada sebanyak 8 orang $(19,05 \%)$ sedangkan kategori tidak setuju dan sangat tidak setuju tidak ada jawaban responden. Adapun nilai ratarata adalah 4,10. Hal ini menunjukkan bahwa karyawan selalu mematuhi standar yang ditetapkan oleh perusahaan adalah setuju.

Sehubungan dengan tanggapan responden terhadap indikator beban kerja,maka dapat dilihat hasil penelitian anggapan responden adalah 125 (24,80\%) responden yang berada pada kategori sangat setuju, 285(56,55\%) responden berada pada kategori setuju, 91 (18,05\%) respondenberada pada kategori cukup setuju, $3(0,60 \%)$ responden berada pada kategori tidak setuju sedangkan pada kategori sangat tidak setuju tidak ada jawaban responden. Adapun nilai rata-rata adalah 4,06. Secara rata-rata dapat disimpulkan bahwa jawaban responden terhadap rekapitulasi produktivitas kerja karyawan adalah setuju. Hasil penelitian sehubungan dengan produktivitas kerja karyawan maka dapat diketahui bahwa indikator produktivitas kerja karyawan yang paling mempengaruhi adalah karyawan selalu berusaha dalam mengembangkan kemampuannya.

\section{Analisis Data Dan Pengujian Hipotesis Uji Instrument Data Uji Validitas}

Uji validitas dilakukan dengan menggunakan rumus korelasi product moment, $r$ hitung diperoleh dari hasil output. Nilai tersebut selanjutnya dibandingkan dengan nilai $r$ tabel dari buku statistic SPSS.17.0.

Pengujian validitas beban kerja dapat dilihat selengkapnya dari tabel 16 berikut ini :

Tabel 9. Hasil Pengujian Validitas Variabel Beban Kerja.

\begin{tabular}{llll}
\hline No Butir Pernyataan & r hitung & r tabel & Keterangan \\
\hline Pernyataan 1 & 0,530 & 0,304 & Valid \\
Pernyataan 2 & 0,540 & 0,304 & Valid \\
Pernyataan3 & 0,713 & 0,304 & Valid \\
Pernyataan4 & 0,628 & 0,304 & Valid \\
Pernyataan5 & 0,682 & 0,304 & Valid \\
Pernyataan6 & 0,624 & 0,304 & Valid \\
Pernyataan7 & 0,755 & 0,304 & Valid \\
Pernyataan8 & 0,777 & 0,304 & Valid \\
Pernyataan9 & 0,690 & 0,304 & Valid \\
\hline
\end{tabular}

Sumber : Data Olahan SPSS. 17, 2018 
Dari tabel 9 dapat dilihat bahwa semua indikator yang digunakan untuk mengukur indikator pada variabel beban kerja mempunyai koefisien korelasi yang lebih besar dari pada $r$ tabel untuk sampel sebanyak 42orang responden yaitu 0,304 yang disajikan pada tabel . Dari hasil tersebut menunjukan bahwa semua indikator pada variabel beban kerja tersebut dinyatakan valid.

Selanjutnya untuk menguji validitas pada variabel produktivitas kerja karyawan dapat dilihat dari tabel 10 berikut ini :

Tabel 10.

Hasil Pengujian Validitas Variabel Produktivitas Kerja Karyawan

\begin{tabular}{llll}
\hline No Butir Pernyataan & r hitung & r tabel & Keterangan \\
\hline Pernyataan 1 & 0,541 & 0,304 & Valid \\
Pernyataan 2 & 0,673 & 0,304 & Valid \\
Pernyataan 3 & 0,634 & 0,304 & Valid \\
Pernyataan 4 & 0,518 & 0,304 & Valid \\
Pernyataan 5 & 0,482 & 0,304 & Valid \\
Pernyataan 6 & 0,610 & 0,304 & Valid \\
Pernyataan 7 & 0,646 & 0,304 & Valid \\
Pernyataan 8 & 0,667 & 0,304 & Valid \\
Pernyataan 9 & 0,707 & 0,304 & Valid \\
Pernyataan 10 & 0,690 & 0,304 & Valid \\
Pernyataan 11 & 0,656 & 0,304 & Valid \\
Pernyataan 12 & 0,323 & 0,304 & Valid \\
\hline
\end{tabular}

Sumber : Data Olahan SPSS. 17, 2018

Dari tabel 10 dapat dilihat bahwa

semua indikator yang digunakan

untuk mengukur indikator pada variabel produktivitas kerja karyawan mempunyai koefisien korelasi yang lebih besar dari $r$ tabel untuk sampel sebanyak 42 orang responden yaitu 0,304 yang disajikan pada tabel . Dari hasil tersebut menunjukan bahwa semua indikator pada variabel

produktivitas kerja karyawan tersebut dinyatakan valid.

\section{Uji Reliabilitas}

Pengujian reliabilitas dalam penelitian ini adalah dengan menggunakan rumus Cronbach Alpha. Hasil pengujian reliabilitas untuk masing-masing item yang dilihat dari tabel 18 berikut ini :

Tabel 11.

Hasil Pengujian Validitas Variabel Produktivitas Kerja Karyawan

\begin{tabular}{lll}
\hline Variabel & Cronbac's Alpha & N of Item \\
\hline Beban Kerja (X) & 0,839 & 9 \\
Produktivitas Kerja Karyawan (Y) & 0,837 & 12 \\
\hline Dari tabel 11 dapat dlihat kedua & kuisioner adalah reliable yang berarti \\
mempunyai koefisien alpha yang & bahwa kuisioner yang digunakan dalam \\
besar yaitu di atas 0,8 (sangat kuat) & penelitian ini adalah kuisioner yang handal.
\end{tabular}

sehingga dapat dikatakan semua konsep pengukuran masing-masing variabel dari 


\section{Uji Normalitas}

Uji ini bertujuan untuk menguji apakah dalam model regresi, variabel dependen dan variabel independent mempunyai distribusi data normal atau mendekati normal. Kita dapat melihatnya dari normal probability plot yang membentuk suatu garis diagonal dan ploting data yang akan dibandingkan dengan garis diagonalnya. Jika data menyebar disekitar garis diagonal dan mengikuti arah garis diagonal/grafik histogram maka menunjukkan pola distribusi normal. Apabila data jauh dari garis diagonal dan atau tidak mengikuti arah garis diagonal/grafik histogram maka menunjukkan pola distribusi tidak normal.

\section{Regresi Linear Sederhana}

Berdasarkan data dari 42 orang responden, setelah dilakukan pengujian adapun persamaan regresinya adalah dengan menggunakan rumus SPSS. 17.0 didapat nilai $\mathrm{a}=20,214, \mathrm{~b}=0,789$, maka persamaan regresi linear sederhana adalah sebagai berikut :

$Y=20,214+0,789 X$
Berdasarkan persamaan di atas maka :

1. Konstanta 20,214. Berarti saat beban kerja diabaikan atau nol maka produktivitas kerja karyawan sebesar 20,214 .

2. Koefisien variabel beban kerja (X) 0,789 . Berarti jika variabel beban kerja di naikkan 1 satuan, maka produktivitas kerja karyawan pada PT. Bank Syariah Mandiri Cabang Harapan Raya Pekanbaru akan naik sebesar 0,789 satuan. Koefisien variabel beban kerja bertanda positif. Berarti semakin meningkat beban kerja yang diberikan maka produktivitas kerja karyawan pada PT. Bank Syariah Mandiri Cabang Harapan Raya Pekanbaru akan meningkat.

\section{Uji Koefisien Determinasi (R2)}

Untuk mengetahui besarnya pengaruh beban kerja terhadap produktvitas kerja karyawan pada PT. Bank Syariah Mandiri Cabang Harapan Raya Pekanbaru digunakan koefisien determinasi (R2), setelah dilakukan pengolahan data dapat dilihat pada tabel 19 berikut ini :

Tabel 12.

Hasil R-Square (Koefisien Determinan)

\begin{tabular}{lllll}
\hline Model & $\mathrm{R}$ & R Square & $\begin{array}{l}\text { Adjusted } \mathrm{R} \\
\text { Square }\end{array}$ & $\begin{array}{l}\text { Std. Error of } \\
\text { the Estimate }\end{array}$ \\
\hline 1 & $.669 \mathrm{a}$ & .448 & .434 & 3.61162 \\
\hline
\end{tabular}

a. Predictors: (Constant),

b. Dependent Variable: Produktivitas

Sumber : Data Olahan SPSS. 17, 2018.

Dari tabel 12 dapat diperoleh nilai rsquare (koefisien determinasi) sebesar 0,448. Hal iniberarti beban kerja memberikan sumbangan pengaruh terhadap produktivitas kerja karyawan padaPT. Bank Syariah Mandiri Cabang Harapan Raya Pekanbaru sebesar 44,8\% sedangkan sisanya sebesar (100\%-44,8\%) $=55,2 \%$ dipengaruhi oleh variabel lain diluar variabel dalam penelitian ini.
Uji t

Uji t digunakan untuk mengetahui apakah variabel independen secara parsial berpengaruh positif dan signifikan terhadap variabel dependen. bahwa nilai thitungbeban kerja (X) sebesar 5,699. Tingkat signifikan penelitian ini adalah 5\% atau 0,025 (Uji 2 sisi).Untuk melakukan uji t maka dilakukan langkah-langkah sebagai berikut : 
Tingkat signifikan penelitian ini adalah 5\% atau 0,025 (Uji 2 sisi). Berarti di dapat ttabel sebesar 2,021. Maka terbukti bahwa :

a. Beban kerja $(X)=$ dengan thitung 5,699 lebih besar dari ttabel 2,021dengan tingkat signifikan 0,000 lebih kecil dari 0,05. Maka Ho ditolak dan $\mathrm{Ha}$ diterima, artinya variabelbeban kerja (X) berpengaruhpositif dan signifikan terhadap produktivitas kerja karyawan pada PT. Bank Syariah Mandiri Cabang Harapan Raya Pekanbaru.

\section{SIMPULAN}

Berdasarkan hasil penelitian yang telah dilakukan mengenai pengaruh beban kerja terhadap produktivitas kerja karyawan pada PT. Bank Syariah Mandiri Cabang Harapan Raya Pekanbaru, maka berikut ini penulis mengambil kesimpulan yaitu:

1. Persamaan regresi linear sederhana adalah sebagai berikut :

$\mathrm{Y}=20,214+0,789 \mathrm{X}$, maka dapat dilihat konstanta sebesar 20,214. Berarti saat beban kerja diabaikan atau nol maka produktivitas kerja karyawan sebesar 20,214, sedangkan beban kerja (X) terhadap produktivitas kerja karyawan adalah positif terbukti dari hasil $\mathrm{b}=$ 0,789 yang berarti bahwa setiap kenaikan variabel beban kerja satu satuan akan dapat menaikan produktivitas kerja karyawan padaPT. Bank Syariah Mandiri Cabang Harapan Raya Pekanbaru sebesar 0,789 satuan.

2. Nilair-square (koefisien determinasi) sebesar 0,448. Hal ini berarti beban kerja memberikan sumbangan pengaruh terhadap produktivitas kerja karyawan pada PT. Bank Syariah Mandiri Cabang Harapan Raya Pekanbaru sebesar 44,8\% sedangkan sisanya sebesar $(100 \%-44,8 \%)=$ $55,2 \%$ dipengaruhi oleh variabel lain diluar variabel dalam penelitian ini.
3. Variabel beban kerja $(\mathrm{X})=$ dengan thitung 5,699 lebih besar dari ttabel 2,021 dengan tingkat signifikan 0,000 lebih kecil dari 0,05. Maka Ho ditolak dan Ha diterima artinya variabel beban kerja (X) berpengaruh positif dan signifikan terhadapproduktivitas kerja karyawan pada PT. Bank Syariah Mandiri Cabang Harapan Raya Pekanbaru. Penelitian ini memperkuat/membenarkan penelitian yang telah dilakukan oleh peneliti sebelumnya yang penulis kutip dalam penelitian terdahulu.

4. Variabel produktivitas kerja (Y) bahwa semua indikator yang digunakan untuk mengukur indikator variabel produktivitas kerja karyawan mempunyai koefisien korelasi yang lebih besar dari $r$ tabel untuk sampel sebanyak 42 orang responden yaitu 0,304 .

\section{DAFTAR RUJUKAN}

Ali, M. (2002). Penelitian Pendidikan, Prosedur dan Strategi Mengajar. Bandung: Angkasa.

Arikunto, Suharsimi. (2010). Prosedur Penelitian, Edisi Revisi. Jakarta: Rineka Cipta.

Munandar, A,S. (2001). Psikologi Industri Dan Organisasi. Jakarta: Universitas Indonesia (UI Press).

Bangun, Wilson. (2012). Manajemen Sumber Daya Manusia. Jakarta: Erlangga.

Kasmir. (2012). Dasar-Dasar Perbankan, Edisi Revisi. Jakarta: PT. Raja Grafindo Persada.

Sugiyono. (2010). Metode Penelitian Pendidikan Pendekatan Kuantitatif, kualitatif, dan R\&D. Bandung: Alfabeta.

Sunyoto, Danang. (2012). Teori Kuesioner Dan Analisa Data Sumber Daya Manusia. Yogyakarta: CAPS. 
Sutrisno, Edy. (2015). Manajemen Sumber Daya Manusia. Jakarta: Kencana Prenada Media Group.

Rusby, Z., Arif, M., \& Hidayatullah, A. (2020). Sistem Penilaian Prestasi Kerja pada PT. Bank Negara Indonesia (Persero) Tbk Kantor Cabang Syari'ah Pekanbaru, Riau. COSTING : Journal of Economic, Business and Accounting, 4(1), 34-43.

Tarwaka, Sholicul, LilikSudiajeng. (2004). Ergonomi Untuk Keselamatan, Kesehatan Kerja Dan Produktivitas, Surakarta: UNIBA Press. 